\title{
Influencia de la humedad relativa y la temperatura en las velocidades de corrosión de estructuras de hormigón
}

\author{
Influence of relative humidity and temperature \\ on-site corrosion rates
}

\author{
C. ANDRADE, C. ALONSO y J. SARRÍA \\ Instituto de Ciencias de la Construcción "Eduardo Torroja"-CSIC. Madrid
}

Fecha de recepción: $20-$ III-98

Fecha de aceptación: 13-V-98

ESPAÑA

\begin{abstract}
RESUMEN
Cuando el acero se despasiva, la corrosión se empieza a desarrollar a una velocidad que depende principalmente de la cantidad de humedad contenida en los poros del hormigón. En estructuras expuestas a la atmósfera, este contenido de humedad dependerá, no sólo de la humedad relativa del ambiente, sino también de las variaciones de temperatura que se producen con los ciclos dia-noche. Para avanzar en el conocimiento de la influencia de las variables climáticas en la velocidad de corrosión de estructuras reales, se han llevado a cabo diversos experimentos. Primero se han realizado medidas de corrosión de barras de acero sumergidas en soluciones que simulan la solución de los poros del hormigón sometidas a varias temperaturas y se han registrado sus variaciones de contenido en oxígeno, de la relación $\mathrm{Cl} / \mathrm{OH} y$ de su conductividad. También se han efectuado medidas en probetas de hormigón sometidas a una exposición a la atmósfera no protegidas de la lluvia. Los resultados han permitido deducir que las variaciones de temperatura tienen un efecto múltiple en los diversos parámetros, que se contrapesan unos a otros. Asi, el oxígeno y el pH disminuyen al elevarse la temperatura pero la proporción de $\mathrm{Cl}$ aumenta. La resistividad es el parámetro que mejor se ajusta a las variaciones de la velocidad de corrosión.
\end{abstract}

\begin{abstract}
SUMMARY
When the steel rebar depassivates, the corrosion starts to develop at a rate which mainly depends upon the moisture content in the concrete pores. In natural outdoor exposure conditions, the moisture content will depend not only on the relative humidity of the atmosphere but also upon the temperature cycling occurring from day to night. In order to progress in the understanding of the influence of the climatic variables on the corrosion rate of real size structures, several experiments have been performed. Thus the corrosion is measured in solutions simulating the concrete pore solution and simultaneous measurement of oxygen content, $\mathrm{Cl} / \mathrm{OH}$. ratio and conductivity were made. As well measurements in concrete specimens submitted to outdoor conditions was made. The results enable to deduce that the variation of temperature has a multiple simultaneous effect on different parameters which may counter-balance each-other. Thus the oxygen content and the $\mathrm{pH}$ decrease and the $\mathrm{Cl}$ increase when temperature rises. The best fit of Icorr is found with resistivity.
\end{abstract}

\section{INTRODUCCIÓN}

Los factores que influyen en el desarrollo de la corrosión de las armaduras son: a) la cantidad de cloruros (principalmente la relación $\mathrm{Cl}^{-} / \mathrm{OH}^{-}$), b) los efectos de la actuación de macropares, c) la cantidad de

\section{INTRODUCTION}

The factors which influence the development of the corrosion of reinforcements are: a) the amount of chlorides (mainly the $\mathrm{Cl} / \mathrm{OH}^{-}$ratio), b) macrogalvanic 
humedad de los poros que controla la resistividad eléctrica del hormigón y el acceso de oxígeno y d) la temperatura (1).

La influencia cuantitativa de los dos últimos factores sobre la velocidad de corrosión de la armadura del hormigón, ha sido ya estudiada a nivel del laboratorio por diversos autores (1-5). En estos experimentos la humedad relativa $H R$, y la temperatura, $T^{a}$, se han variado secuencialmente, conservando las probetas durante un cierto tiempo en una misma cámara hasta que alcanzan un equilibrio con el ambiente exterior.

Cuando se hace variar la HR y la $\mathrm{T}^{\mathrm{a}}$, la velocidad de corrosión evoluciona progresivamente hasta alcanzar el equilibrio en el nuevo ambiente. Esta evolución puede tardar días o semanas, dependiendo de los valores de HR y Ta iniciales y finales. Los estudios realizados permitieron establecer que la HR tiene una fuerte incidencia sobre el valor estacionario final de la velocidad de corrosión (1-4) mientras que la influencia de la $T^{\mathrm{a}}$ parece menos clara (5) aunque algunos autores afirman que su aumento induce un incremento de la velocidad de corrosión (6).

La forma en que la HR y la $T^{\mathrm{a}}$ evolucionan en las atmósferas reales es, sin embargo, muy diferente a las condiciones que se han usado en el laboratorio. La HR varía muy marcadamente del día a la noche cuando la $T^{a}$ cambia notablemente. La situación es diferente de lugar en lugar y de país en país, pero en general se produce una evolución diaria de tipo sinusoidal de la HR y la $\mathrm{T}^{\mathrm{a}}$. Esta evolución de "corto alcance" se complementa con otra de "largo alcance" que se produce por la evolución estacional, lo que da lugar también a un ciclo anual también de carácter sinusoidal (7) marcado por los extremos verano-invierno.

La influencia de la evolución de los parámetros HR y $\mathrm{T}^{\mathrm{a}}$ en el interior del hormigón se ha empezado a registrar de forma continua, sólo recientemente (7)(8). Aún más reciente es el estudio sobre la incidencia en la velocidad de corrosión. Contrariamente a lo esperado, la relación entre intensidad de corrosión (Icorr) y la HR-T ${ }^{\mathrm{a}}$ no es obvia, y hasta ahora no se ha podido establecer ninguna correlación evidente (7). Por ejemplo, se ha podido comprobar que la lluvia no siempre produce un aumento de la Icorr, sino que éste depende de la duración de la lluvia y de la $\mathrm{T}^{\mathrm{a}}$ particular que esté actuando.

En consecuencia, se ha identificado la necesidad de un estudio más detallado de los factores individuales que afectan a la velocidad de corrosión, así como de la necesidad de un registro continuo de los parámetros climáticos. En este trabajo, se presentan experimentos que se han realizado en momentos especificos de períodos estacionales, además de los ensayos en effects, c) the amount of moisture which affects the concrete resistivity and oxygen avalaibility and d) the temperature ( $I$ ).

The quantitative influence of the last two factors on the corrosion rate has been already studied at laboratory level by several authors (1-5). In these experiments the relative humidity, $R H$ and the temperature, $T$, are changed sequentially, helding the specimens during some time at the same chamber or particular atmosphere in order they can reach a certain equilibrium.

When the RH or the $T$ is changed, the corrosion rate steadely evolves until reaching a new value. This evolution may take days or weeks depending upon the specific initial and final atmospheres. These studies enabled to establish that the RH has a strong influence in the steady state value of the corrosion rate (1-4) while the influence of the $T$ seems less clear (5) although some authors reported that its rise clearly increases the corrosion rate (6).

However, the way the climatic parameter $R H$ and $T$ evolve outdoors is quite different, than the conditions used in the laboratory experiments. The RH evolves from day to night sometimes markedly, due to the daily evolution of $T$. The situation changes from country to country and place to place, but in general a daily sinusoidal evolution of $R H$ and $T^{\circ}$ is recorded. This short time evolution also varies from season to season and it can be also noticed a yearly sinusoid due the winter-summer extreme climates (7).

These continuous changes of $R H$ and $T$ are being recently recorded in real structures (7)(8) and their influence in the corrosion rate is being studied. On the opposite what it was expected, the relationship between corrosion rate (Icorr) and RH-T is not obvious, and any particular correlation has been found until now (7). For instance, it was noticed the raining not always means an increase of the corrosion rate, but depends on the length of the raining and of the $T$.

In consequence, it has been identified the need of a more detailed study of the individual factors affecting the corrosion rate, as well as the need of a continuous monitoring in outdoor exposure of climatic parameters. In present paper results are presented on trials that have been performed at particular seasonal moments, in addition to the experiments of rebars submerged in 
disolución que simula la solución contenida en los poros del hormigón a diferentes $\mathrm{T}^{\mathrm{a}}$, con el fin de avanzar en el conocimiento de los factores que controlan la evolución de la velocidad de corrosión en estructuras reales expuestas a la atmósfera.

\section{PARTE EXPERIMENTAL}

Los tres tipos de ensayos que se han realizado son:

1) Ensayos en disolución que simulan la fase acuosa de los poros del hormigón (FAP).

2) Ensayos en probetas de hormigón que se conservan en atmósferas de humedad relativa, RH y temperatura, $\mathrm{T}^{\mathrm{a}}$, controladas. En la tabla 1 se muestran las condiciones ensayadas.

3) Ensayos en las mismas probetas de hormigón pero expuestas al exterior.

Los parámetros que se han medido son:

Disoluciones - $\mathrm{pH}$, concentración de cloruros, conductividad contenido de oxígeno al final de los ensayos, potencial de corrosión, Ecorr e intensidad de corrosión, Icorr.

Hormigón -RH y T ${ }^{\mathrm{a}}$ en el interior (en una cavidad, como se muestra en la figura 1) y la resistividad eléctrica, a lo largo de todo el experimento (a través de la medida de la caída ohmica, Re).

Además, en ambos casos, se ha medido el potencial de corrosión, Ecorr y la intensidad de corrosión, Icorr en las barras sumergidas en las disoluciones o embebidas en el hormigón. Estas medidas se han realizado mediante el método de la Resistencia de Polarización (1).

Las disoluciones que se prepararon fueron:

1) Agua destilada

2) Solución saturada de $\mathrm{Ca}(\mathrm{OH})_{2}+0,2 \mathrm{M} \mathrm{KOH}+0,1$ $\mathrm{M} \mathrm{NaCl}$ synthetic pore solutions at different $T$, in order to gain understanding on the key factors governing the corrosion rate evolution in real size structures located outdoors.

\section{EXPERIMENTAL}

Three sets of experiments will be reported:

1) Tests in solutions simulating the pore concrete solution (FAP).

2) Tests in concrete specimens submitted to atmospheres of controlled RH and T. Table 1 shows the conditions tested.

3) Tests on the same type of concrete specimens but exposed outdoors.

The parameters that have been monitored were:

Solutions - $p H$; chloride concentration, conductivity, oxygen content, corrosion potential, Ecorr and corrosion rate, Icorr.

Concrete -internal $R H$ and $T$ (in a cavity as is shown in figure I), concrete resistivity (through the ohmic drop $R e)$, Ecorr and Icorr of the bars embedded.

The Ecorr, Re and Icorr have been measured by means of the Polarization Resistance method (1).

The solutions used were.

1) Distilled water

2) Saturated solution of $\mathrm{Ca}(\mathrm{OH})_{2}+0.2 \mathrm{M} \mathrm{KOH}+0.1$ $\mathrm{MNaCl}$

TABLA 1 (TABLE I)

Condiciones de $\mathrm{T}^{\mathrm{a}}$ y $\mathrm{RH}$ en las cámaras (Conditions of $T$ and $R H$ of the controlled chambers)

\begin{tabular}{|c|c|c|c|c|c|}
\hline $\mathrm{T}^{\mathrm{a}}\left({ }^{\circ} \mathrm{C}\right)$ & \multicolumn{5}{|c|}{ Humedad Relativa \% (Relative Humidíty \%) } \\
\hline $2-3$ & 50 & 80 & & 100 & Tot. Imm \\
\hline 20 & 50 & 80 & 90 & 100 & Tot. Imm \\
\hline 40 & 50 & & 90 & 100 & Tot. Imm \\
\hline
\end{tabular}




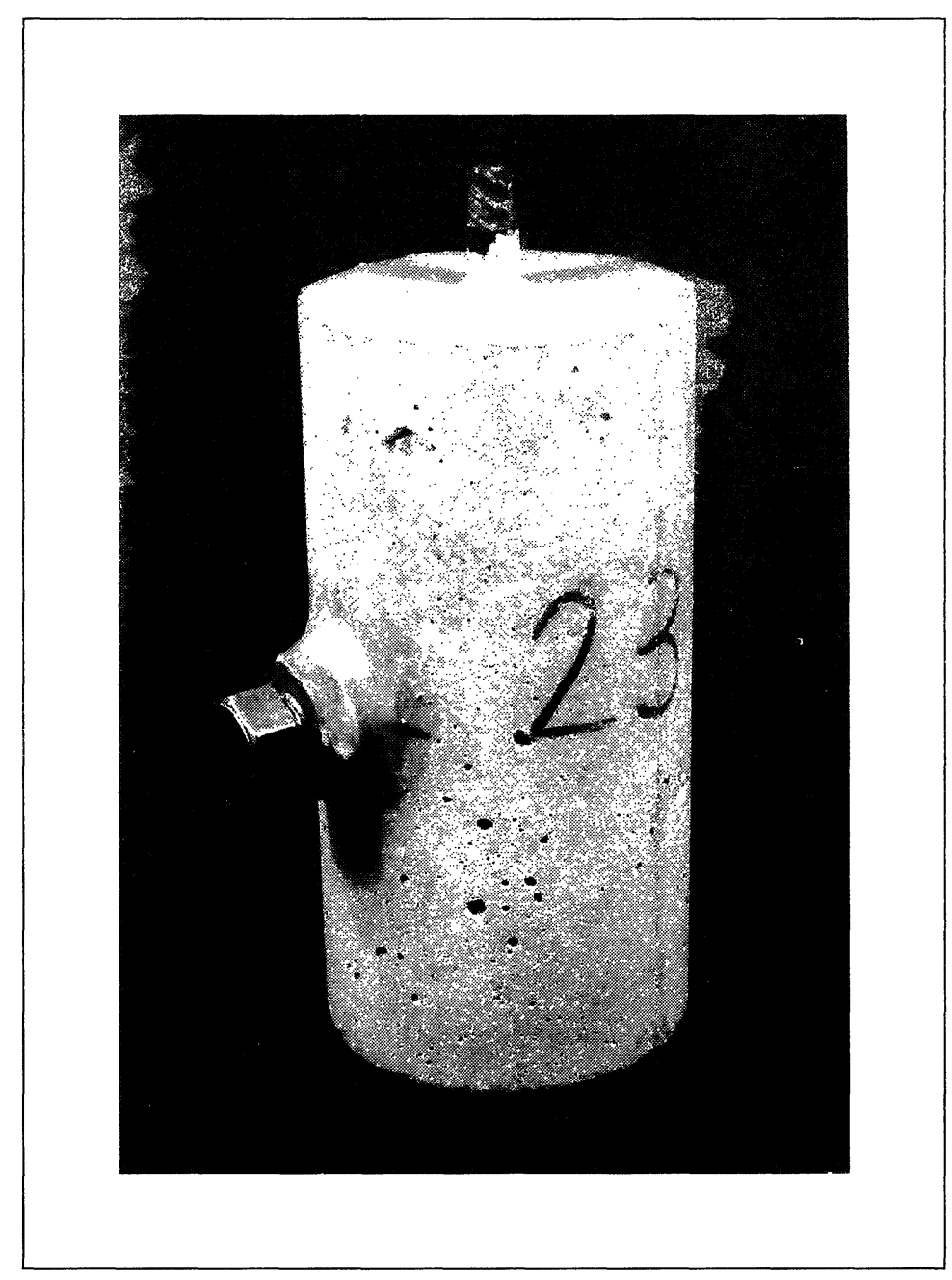

Fig. 1.-Probeta de hormigón de $7,5 \times 15 \mathrm{~cm}$, mostrando el dispositivo que hace de tapa de la cavidad donde se mide, periódicamente, la HR.

Fig. 1.- Concrete specimen showing the aspect of the device used for isolating the cavity where $R H$ is measured.

3) Solución saturada de $\mathrm{Ca}(\mathrm{OH})_{2}+0,2 \mathrm{M} \mathrm{KOH}+0,5 \mathrm{M}$ $\mathrm{NaCl}$

Las medidas se realizaron durante un período de 60 días.

Las probetas de hormigón fueron cilíndricas, de $7,5 \mathrm{~cm}$ de diámetro y $15 \mathrm{~cm}$ de altura, que se fabricaron con un cemento tipo I-45A. Las proporciones de cemento que se utilizaron fueron de 250 y de $350 \mathrm{~kg}$ con una relación a/c de 0,5 en las probetas que luego se carbonataron de forma acelerada. En las probetas a las que se les añadió 1 y $3 \%$ de $\mathrm{NaCl}$ respectivamente, se utilizaron $300 \mathrm{~kg}$ de cemento $/ \mathrm{m}^{3}$ de hormigón con una relación a/c de 0,6 . En todos los casos el tamaño máximo de árido fue de $12 \mathrm{~mm}$ y el tiempo de curado de 3 días. Así pues, se prepararon 4 series de probetas: dos carbonatadas (dos proporciones de cemento diferentes) y dos con cloruros (dos proporciones de cioruro).
3) Saturated solution of $\mathrm{Ca}(\mathrm{OH})_{2}+0.2 \mathrm{M} \mathrm{KOH}+0.5 \mathrm{M}$ $\mathrm{NaCl}$.

The test was carried out along 60 days.

The concrete specimens were cylindrical of $7.5 \times 15 \mathrm{~cm}$ in size. They were fabricated with an OPC. The proportions of cement were 250 and $350 \mathrm{~kg} / \mathrm{m}^{3}$ in the carbonated specimens with $w / c=0.5$ and $300 \mathrm{~kg}$ cement $/ \mathrm{m}^{3}$ and $w / c=0.6$ in the chloride contains specimens. The maximum aggregate size was of $12 \mathrm{~mm}$. A central bar of $8 \mathrm{~mm}$ in diameter was embedded in each specimen. Two set of specimen were carbonated artificially after a curing period of 3 days under water and several weeks of drying and other two set specimens were mixed with chlorides (I and 3\% of $\mathrm{NaCl}$ by weight of cement). Four variables were therefore tested: carbonated with two different concrete 
Una serie de estas probetas fueron introducidas en diferentes cámaras con las combinaciones de $\mathrm{HR}$ y $\mathrm{T}^{\mathrm{a}}$ que se muestran en la tabla 1. Otra serie fue colocada en el jardín exterior en distintas condiciones de acción directa o no (protegidas) de la lluvia y con soleamientos directo o no.

\section{RESULTADOS}

\section{Ensayos en disolución}

La figura 2 resume todos los resultados obtenidos, con los parámetros estudiados. El aspecto más relevante a qualities, and uncarbonated with two proportions of admixed chlorides. A set of these specimens were submitted in different chambers to the combinations of RH and $T$ shown in table 1. Another set was placed outdoors in the garden and in different locations sheltered and non sheltered from rain and with or without direct sun action.

\section{RESULTS}

\section{Tests in solution}

Figure 2 summarizes all the parameters recorded in the solutions. Several interesting features could be

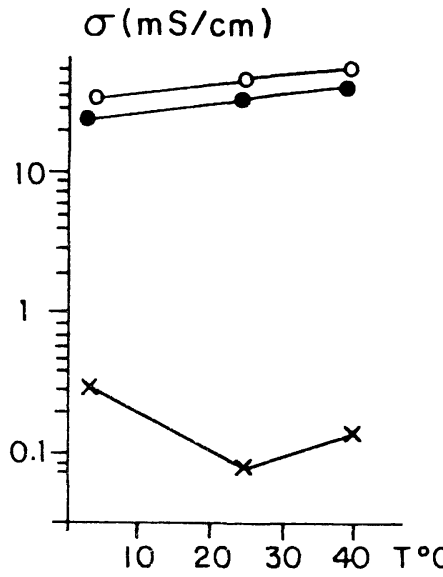

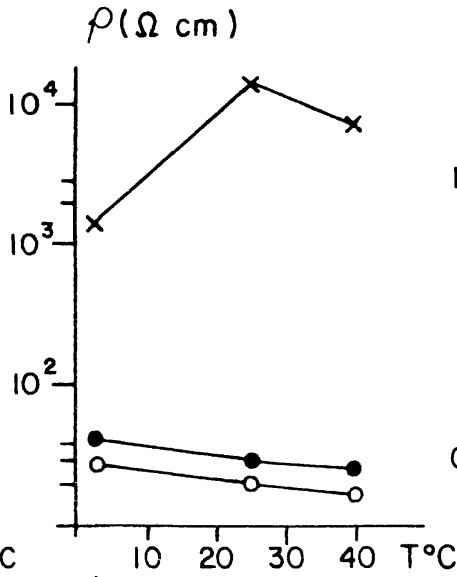

a)

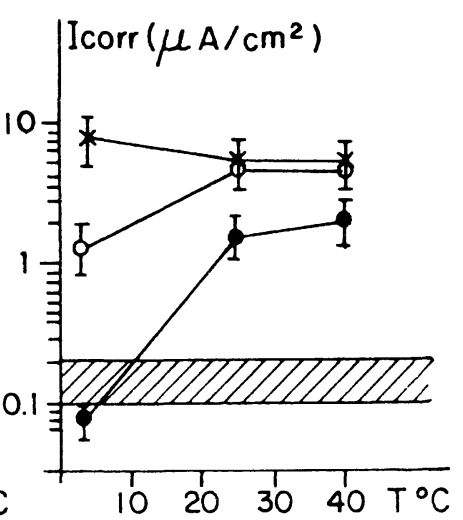

e)

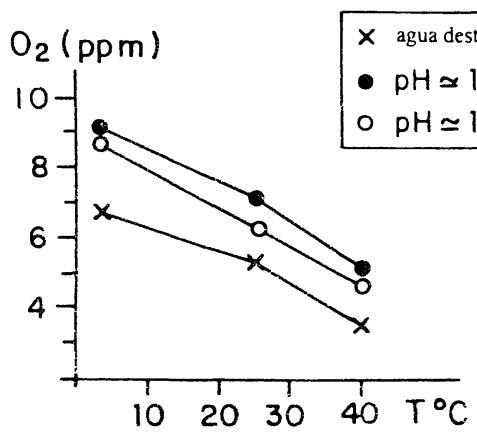

b)

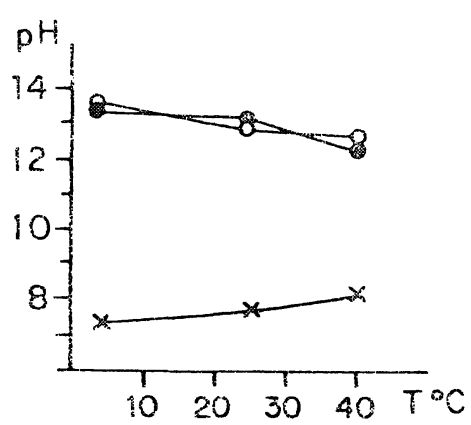

f)

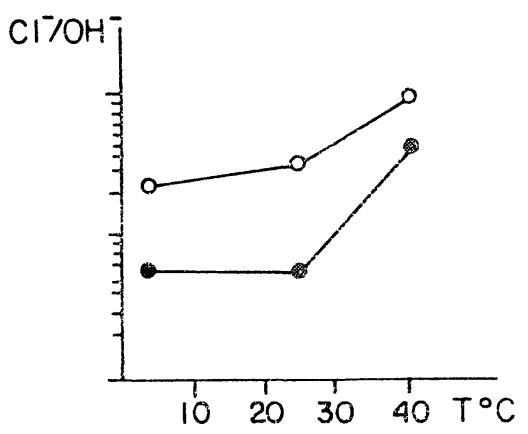

c)

d)

Fig. 2.- Ensayos de disolución: influencia de la temperatura en: a) la conductividad $(\sigma)$ y resistividad ( $\rho$ ), b) en el contenido de oxigeno, c) el valor del $\mathrm{pH}, \mathrm{d})$ la relación $\mathrm{Cl} / \mathrm{OH}$, e) la lcorr y f) el Ecorr.

Fig. 2.- Tests in solution: influence of temperature in: a) conductivity $(\sigma)$ and resistivity $(\rho)$, b) in oxygen content, c) pH value, d) Cl/OH ratio, e) Icorr and J) Ecorr. 
destacar es el hecho de que la Icorr casi no varía para el rango de $\mathrm{T}^{\mathrm{a}}$ entre 25 y $40^{\circ} \mathrm{C}$, mientras que decrece claramente entre 25 y $3{ }^{\circ} \mathrm{C}$ en las disoluciones alcalinas, mientras que aumenta ligeramente en el agua destilada que simula una FAP carbonatada.

Este inesperado resultado se puede justificar al observar el comportamiento del resto de los parámetros, ya que al aumentar la $\mathrm{T}^{\mathrm{a}}$ desde 3 a $40^{\circ} \mathrm{C}$ se observa que:

- El contenido en $\mathrm{O}_{2}$ disminuye de forma importante y la conductividad aumenta excepto en el agua destilada, donde se observa un mínimo a $25^{\circ} \mathrm{C}$ (hay que tener en cuenta a este respecto que la conductividad se mide al final del ensayo cuando ya se han producido óxidos).

- El valor del pH aumenta en el agua destilada y disminuye en las alcalinas (este último hecho se atribuye a la disminución en solubilidad del $\mathrm{Ca}(\mathrm{OH})_{2}$ cuando la $T^{\mathrm{a}}$ aumenta).

- El valor de la relación $\mathrm{Cl}^{-} / \mathrm{OH}^{-}$aumenta debido a la disminución de los $\mathrm{OH}^{-}$y aumento de la solubilidad de los $\mathrm{Cl}^{-}$.

\section{Ensayos en hormigón}

Para los ensayos en atmósferas controladas, la figura 3 muestra como ejemplo la evolución de la Icorr a lo largo identified from these results. The most relevant is the fact that the Icorr almost does not change when the $T$ ranges between 25 and $40{ }^{\circ} \mathrm{C}$, while it decreases when going from 25 to $3{ }^{\circ} \mathrm{C}$ for the alkaline solution, and it increases in the case of distilled water which simulates the pore solution of a carbonated concrete.

This particular behaviour can be justified by looking at the other parameters measured. Thus when rising $T$ from 3 to $40^{\circ} \mathrm{C}$ :

- The oxygen content markedely decreases and the conductivity increases except for the distilled water where a minimum at $25^{\circ} \mathrm{C}$ is noticed (it has to take into account that the conductivity is measured at the end of the test when some oxydes have been already produced).

- The pH value increases in the distilled water and decreases in the alkaline ones (this last is attributed to the decrease in solubility of the $\mathrm{Ca}(\mathrm{OH})_{2}$, when $\mathrm{T}$ increases).

- The $\mathrm{Cl} / \mathrm{OH}$ increases due the depletion of $\mathrm{OH}^{-}$and the increase of solubitity $\mathrm{Cl}^{-}$.

\section{Tests in concrete specimens}

For the tests in the controlled chambers figure 3 shows the evolution of Icorr along the time for the case of $3 \%$

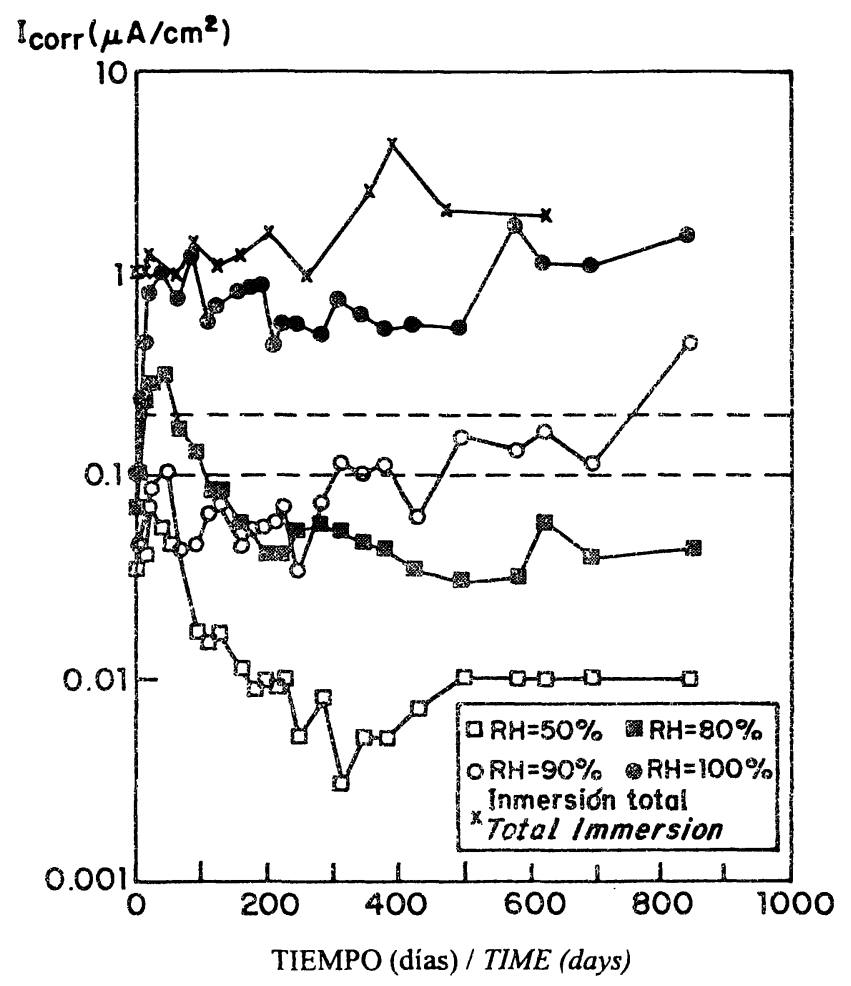

Fig. 3.- Ejemplo de evolución de la Icorr con el tiempo en la probeta de hormigón conteniendo $3 \% \mathrm{de} \mathrm{NaCl}$ a las cinco humedades ensayadas.

Fig. 3.- Example of evolution of Icorr along time in the concrete specimen with $3 \%$ of $\mathrm{NaCl}$ at the five humidities tested. 
del tiempo para la probeta con el $3 \%$ de $\mathrm{NaCl}$, mientras que la figura 4 resume los valores de Icorr al año de vida de las probetas para las cuatro series estudiadas en todas las condiciones ensayadas.
$\mathrm{NaCl}$ as an example while. Figure 4 summarizes the Icorr values after one year of testing of the four variables studied in concrete, for all the conditions studied.

\section{$\left(250 \mathrm{~kg} / \mathrm{m}^{3}\right)$}

\section{$\left(350 \mathrm{~kg} / \mathrm{m}^{3}\right)$}

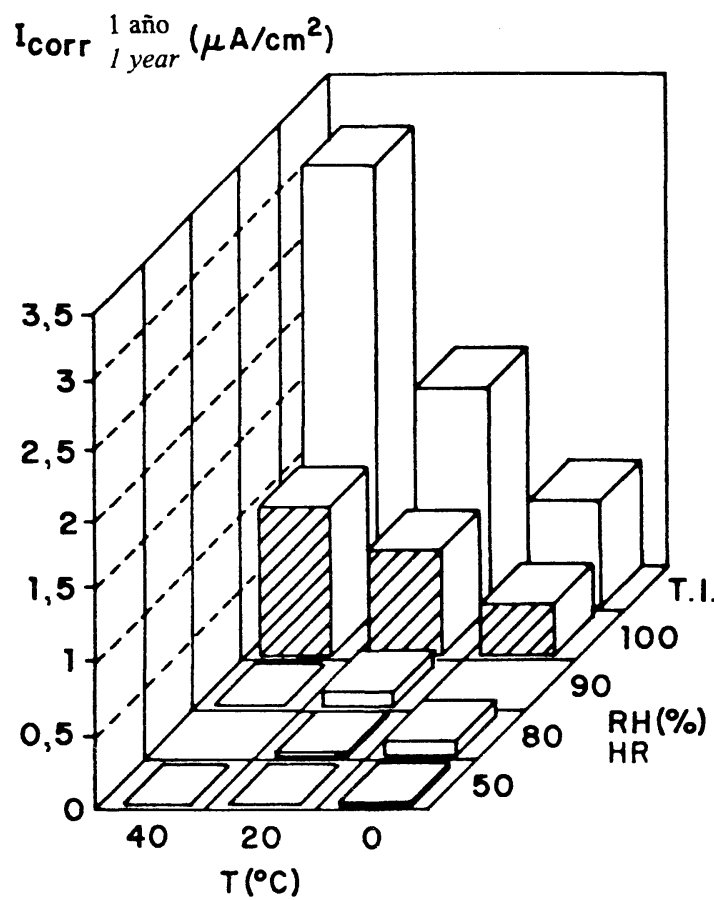

$1 \% \mathrm{NaCl}$

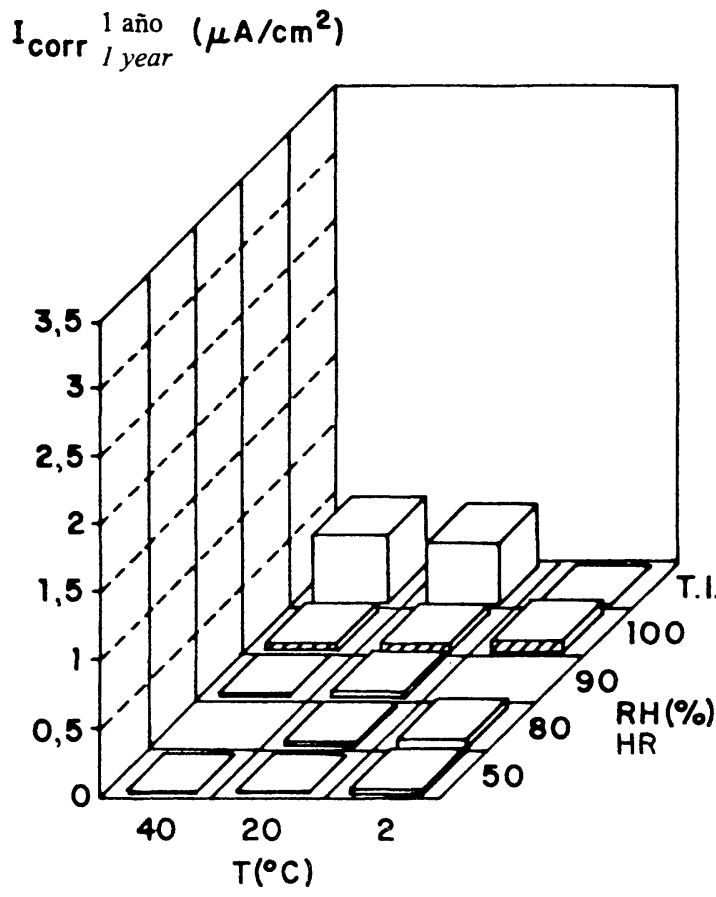

$3 \% \mathrm{NaCl}$
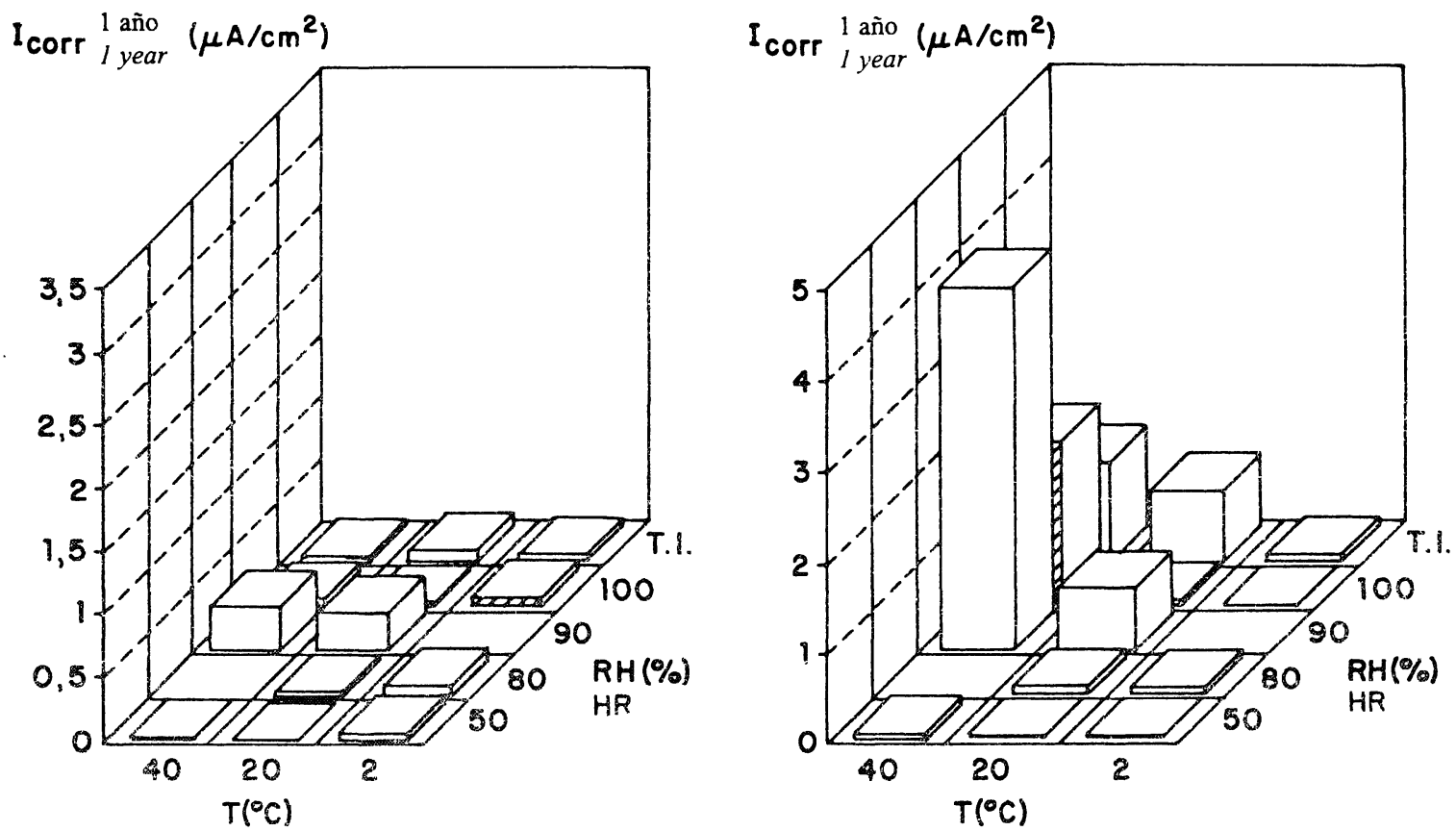

Fig. 4.- Valores de Icorr, después de un año de ensayo, de las probetas sometidas a las condiciones de la tabla 1 en cámaras controladas.

Fig. 4. - Icorr values, after I year testing, of the rebars embedded in the concrete specimens submitted to the conditions of table I in controlled chambers. 
En las probetas carbonatadas se puede observar que sólo presentan elevados valores de Icorr para HR $>90 \%$ y que la Icorr aumenta cuando la $\mathrm{T}^{\mathrm{a}}$ aumenta. Sin embargo, los valores máximos de Icorr en las probetas contaminadas con cloruros, se obtienen para valores intermedios de $\mathrm{RH}$, aumentando también las Icorr con la temperatura.

La figura 5 muestra, también, a modo de ejemplo, los valores de Icorr en las probetas conservadas en la atmósfera exterior de Madrid, correspondientes a unos días durante el mes de febrero de 1997 para las cuatro series de probetas. La figura muestra la evolución de la Ta, HR-EXT, HR-IN, Ecorr, $\rho$ y la Icorr.

Se quiere resaltar en la figura, que el descenso de la $\mathrm{T}^{\mathrm{a}}$ a valores inferiores a $0{ }^{\circ} \mathrm{C}$ se realizó de forma artificial mediante la introducción de las probetas en un congelador. Esta acción artificial permitió identificar que este descenso brusco de la $\mathrm{T}^{\mathrm{a}}$ induce cambios muy importantes de todos los parámetros. Así, a) aumenta dramáticamente la $\mathrm{RH}$ y la resistividad, $\rho \mathrm{y}, \mathrm{b}$ ) disminuye la Icorr, evolucionando los Ecorr hacia valores más negativos.

A partir de esta figura 5 se puede deducir también que los valores más elevados de la Icorr se presentan en la probeta carbonatada con la menor proporción de cemento $\left(250 \mathrm{~kg} / \mathrm{m}^{3}\right)$ y en la que contiene un $3 \%$ de $\mathrm{NaCl}$.

\section{DISCUSIÓN}

Trabajos anteriores habían considerado que las variaciones de la Icorr con la $\mathrm{T}^{\mathrm{a}}$ en armaduras embebidas en hormigón seguían la ley de Arrhenius (6). Otros trabajos (7) sin embargo habían postulado lo contrario debido a la evaporación que se induce al aumentar la temperatura o la condensación en los poros capilares cuando desciende, lo que se contrapone a la aceleración previsible debida al aumento de la Icorr. Los resultados aquí presentados confirman el efecto opuesto entre la $\mathrm{T}^{\mathrm{a}} \mathrm{y}$ la Icorr.

Pero, además, estos resultados ofrecen una visión más amplia sobre todos los efectos que pueden generar los ciclos de Ta . Así, los ensayos en disolución han permitido confirmar el descenso en la solubilidad del $\mathrm{Ca}(\mathrm{OH})_{2}$ cuando la $\mathrm{T}^{\mathrm{a}}$ aumenta y el consiguiente descenso del pH y aumento de la relación $\mathrm{Cl} / \mathrm{OH}$. Estos efectos, dificultan que la resistividad siga a su vez la ley de Arrhenius. Por otro lado, el oxígeno también disminuye cuando aumenta la $\mathrm{T}$. La consecuencia final es que la Icorr no varía para el intervalo de $\mathrm{T}^{\mathrm{a}}$ entre 25 y $40^{\circ} \mathrm{C}$, mientras que la Icorr disminuye en agua destilada y aumenta en las soluciones alcalinas para elintervalo 25 a $3{ }^{\circ} \mathrm{C}$.
It can be noticed that carbonated specimens, only present high Icorr values for $H R>90 \%$ and Icorr increases when $T$ does. However, the maximum Icorr values in the chloride contaminated specimens are obtained for intermediate $R H$ values, being also increasing the Icorr trend with a rise in $T$.

Concerning the Icorr values recorded in the specimens exposed to the atmosphere, of Madrid, Figure 5 shows them also as an example. It is the record along several days of the month of february'97 of the four types of specimens. The figure also shows the evolution of $T$, $R H-I N$ and RH-EXT, Ecorr, $\rho$ and Icorr.

It has to be mentioned that the lowering of $T$ to values lower than $0{ }^{\circ} \mathrm{C}$ was artificially obtained by means of introducing the specimens in a fridge. This artificial action enabled to identify that this sudden effect induces dramatic changes in all the parameters. Such a decrease in T induces: a) increases in $\mathrm{RH}$ and resistivity $\rho$ and b) decreases in Ecorr and Icorr.

From the figure 5 it can be also deduced that, the highest values of Icorr are presented by the carbonated specimen with the lowest amount of cement $\left(250 \mathrm{kp} / \mathrm{m}^{3}\right)$ and that with $3 \%$ of admixed $\mathrm{NaCl}$.

\section{DISCUSSION}

It could be expected that the corrosion rate follows Arrhenius law as has been mentioned before (6). However, it has already theoretically analyzed (7) that this cannot happen due to the evaporation of concrete moisture during temperature increase and the condensation after temperatures decrease which counter balance the T effect. Present results confirm this last statement on the opposite effects of $T$ in the Icorr trend.

But present results also offer a much wider approach to the multiple effects induced by T cycles. Thus, the tests in solution indicate the important effect of the decreasing solubility of $\mathrm{Ca}(\mathrm{OH})_{2}$, with $\mathrm{T}$ rise, and the subsequent lowering of $\mathrm{pH}$ and increase in $\mathrm{Cl} / \mathrm{OH}^{-}$ ratio. In turn, this difficults as well the conductivity to fit into Arrhenius law. Oxygen also decreases when $T$ rises. The final consequence is that Icorr almost does not change between 25 and $40^{\circ} \mathrm{C}$ while, it decreases in distilled water and increases in alkaline solutions, when reaching $3{ }^{\circ} \mathrm{C}$. 
En el caso del hormigón, todos estos fenómenos ocurren también simultáneamente con el cambio en el contenido en humedad del hormigón al variar la HR y la Ta
In the case of concrete these effects happen simultaneously to the aforementioned change in pore moisture content with the exterior $T$ and $R H$ variations.
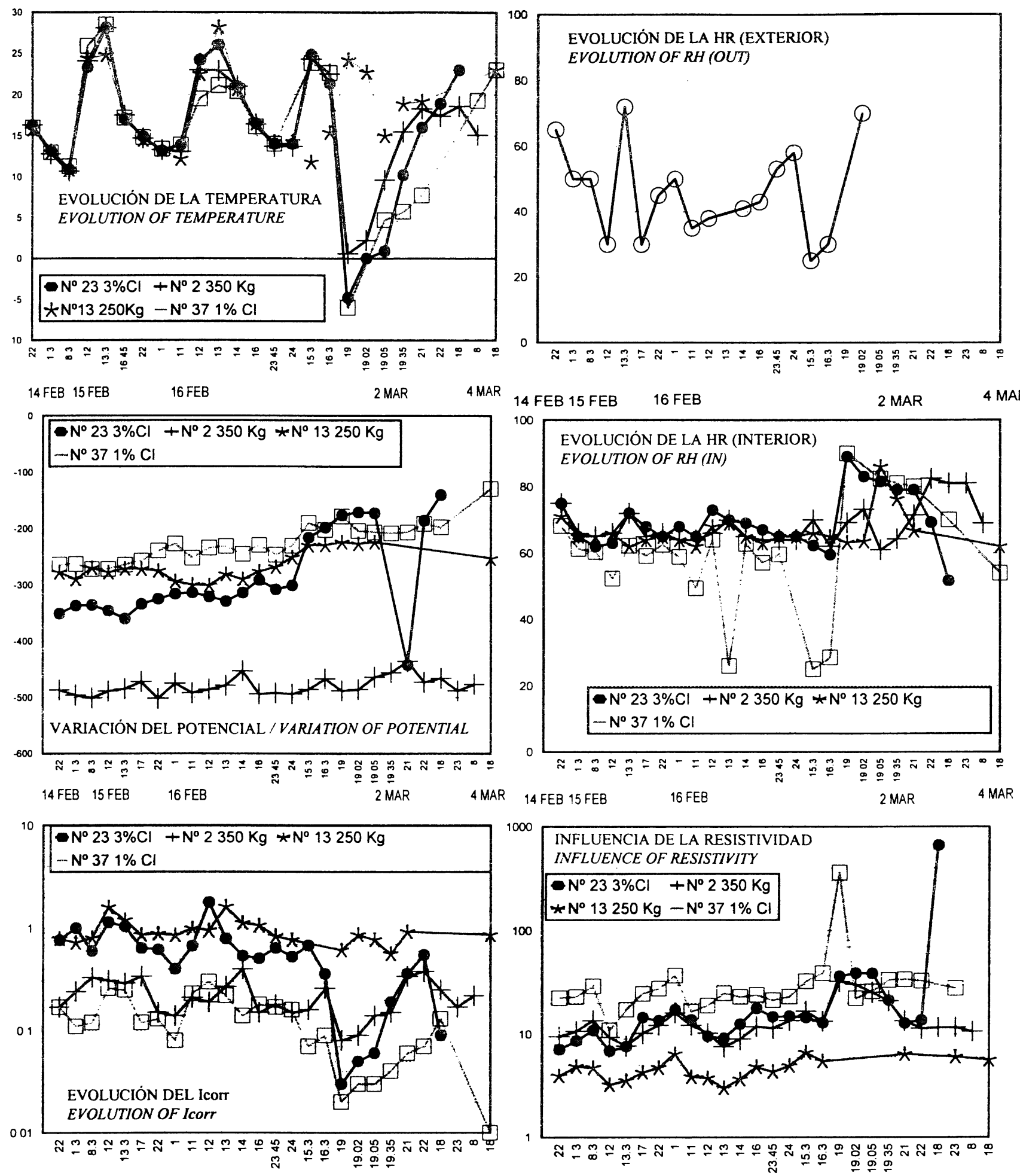

14 FEB15 FEB 16 FEB

2 MAR

4 MAR 9714 FEB15 FEB

16 FEB

2 MAR $\quad 4$ MAR

Fig. 5.- Valores de $T^{\mathrm{a}}, \mathrm{HR}, \rho$, Ecorre Icorr durante el ciclo día-noche para armaduras embebidas en probetas conservadas a la atmósfera exterior. Se muestra la refrigeración artificial de las probetas inducida en la tarde del 16 de febrero.

Fig. 5.- Values of T, RH, $\rho$, Ecorr and Icorr along day-night evolution for rebars embedded in concrete exposed to outdoor conditions. The artificial freezing of the specimens in the evening of the $16^{\text {th }}$ of february is shown. 
exteriores. En las cámaras de atmósferas controladas, parece necesario alcanzar elevados valores de $\mathrm{HR}_{\mathrm{T}} \mathrm{T}^{\mathrm{a}}$ para alcanzar cinéticas de corrosión elevadas, lo que se atribuye al bajo contenido en humedad para HR $90 \%$. Sin embargo en los hormigones contaminados de cloruros, su mayor higroscopicidad y salinidad parecen limitar el contenido en oxígeno a las HR más elevadas, por lo que el máximo en Icorr se obtiene a valores intermedios de HR donde se alcanza el óptimo de acceso de oxígeno.

Cuando se producen los ciclos naturales de HR y $\mathrm{T}^{\mathrm{a}}$ en la atmósfera exterior, el hormigón que rodea la armadura no sufre en la misma amplitud los cambios HR. Así, la figura 6 muestra los cambios registrados en el exterior y en el interior del hormigón, sobre un ábaco psicrométrico (10). Se puede aquí deducir que cuando la $\mathrm{T}^{\mathrm{a}}$ aumenta en el exterior, como la humedad absoluta permanece constante, se produce un descenso de la HR. Sin embargo, en el interior del hormigón (la cavidad) cuando la $T^{a}$ aumenta, la humedad de los poros se evapora lo que hace aumentar la humedad absoluta y, por tanto, casi no se altera la HR dentro de los poros. Este efecto amortiguador de las HR dentro del hormigón hace que la Icorr se comporte de forma muy similar a lo que ocurre en disolución. Por encima de $10^{\circ} \mathrm{C}$, la Icorr sólo aumenta ligeramente con la $\mathrm{T}^{\mathrm{a}}$. Por debajo de $10^{\circ} \mathrm{C}$, la Icorr claramente disminuye, a pesar de la
In chambers with controlled atmospheres, it seems necessary to reach very high values of $R H$ and T to get significant corrosion in the carbonated concretes. This is attributed to the much lower moisture content found for $\mathrm{RH} 90 \%$. However, in chloride containing concretes, their higroscopicity and salinity seem to limit oxygen access at higher $R H$ and the maximum in Icorr is noticed at intermediate $R H$ values, where enough moisture and oxygen seem to exist to develop active corrosion.

When $T$ and RH change in the atmosphere due to the dayly cycles, the concrete near the rebar however does not suffer the same RH changes. Thus, figure 6 shows the evolution of external and internal RH plotted in psicometric abacus (10). It can be well identified that when $T^{\circ}$ rises outdoors, the absolute moisture remains constant and therefore the RH decreases. However, in the concrete cavity when the $T$ increases, the moisture evaporates from the concrete itself, which increases the absolute moisture in the cavity and the $R H$ may remain constant in it. This kind of RH buffering enables the corrosion to behave more similarly to what happens in solution. Above $10^{\circ} \mathrm{C}$ the Icorr does not vary very much due to the $T^{\circ}$ although a slight increase is noticed. Below $10^{\circ} \mathrm{C}$ the Icorr clearly decreases in spite of the

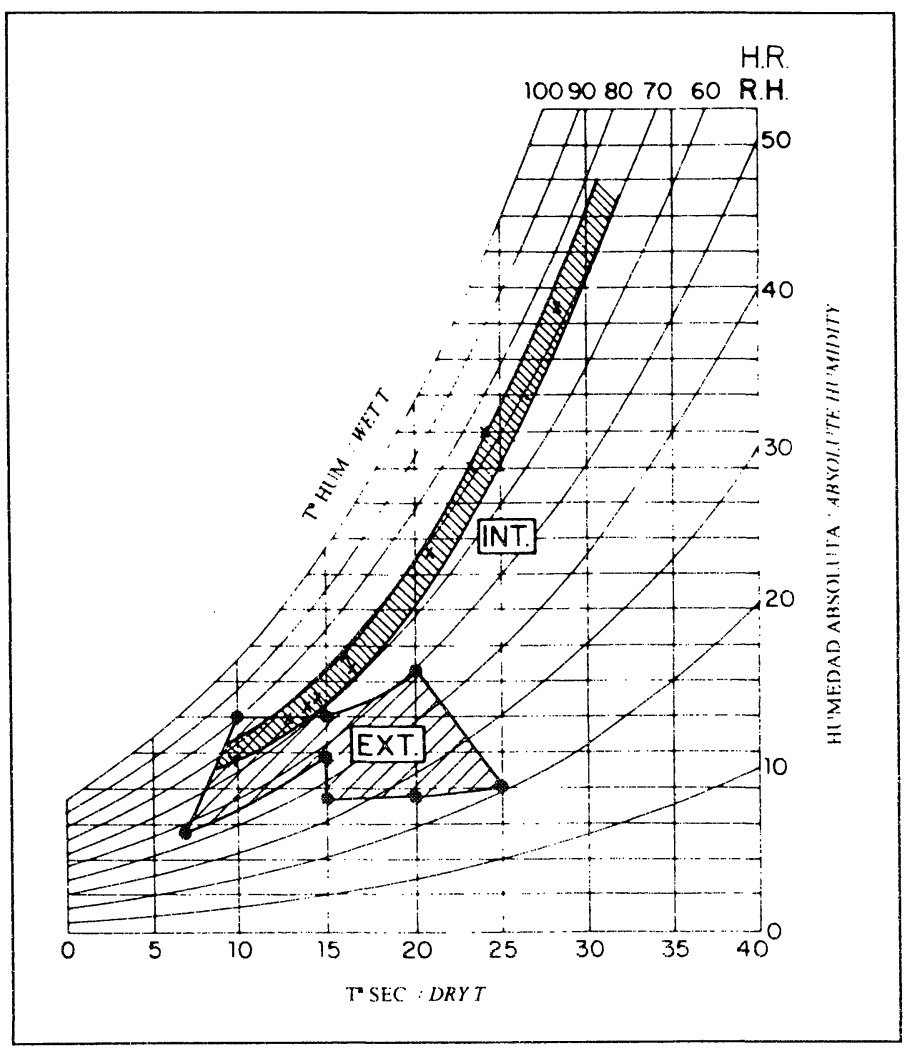

Fig. 6.- Representación en un ábaco psicrométrico de las variaciones de HR exterior y en el interior de la cavidad.

Fig. 6.- Representation in a psycrometric abacus of external RH variations and the values of RH in the concrete cavity. 
condensación que se induce. Las figuras 7 y 8 muestran, respectivamente, el ajuste de Icorr con la $T^{a}$ y con la HR x T ${ }^{a}$. El mejor ajuste se consigue con la Icorr frente a la resistividad (figura 9 ).

Este gráfico confirma la viabilidad de aplicación de la expresión $(11)(12)$ : Icorr $=10^{4} / \rho$, donde Icorr se expresa en $\mu \mathrm{A} / \mathrm{cm}^{2}$ y la $\rho$ en $\Omega \cdot \mathrm{cm}$.

Finalmente, se debe destacar que es necesaria mucha más investigación para lograr establecer un modelo que permita relacionar la Icorr con los cambios climáticos. condensation produced. Figures 7 and 8 depict the fit of Icorr versus $T$ and HR $x T$ respectively. The best fit is obtained for the plotting of Icorr versus resistivity (figure 9).

This plot confirms the feasibility of application of the expression (11)(12): Icorr $=10^{4} / \rho$ where Icorr $=$ $\mu A / \mathrm{cm}^{2}$ and $\rho=\Omega \cdot \mathrm{cm}$.

Finally, it has to be stressed that much more research is needed to find a model which could encounters the whole Icorr trend due to climatic variations.

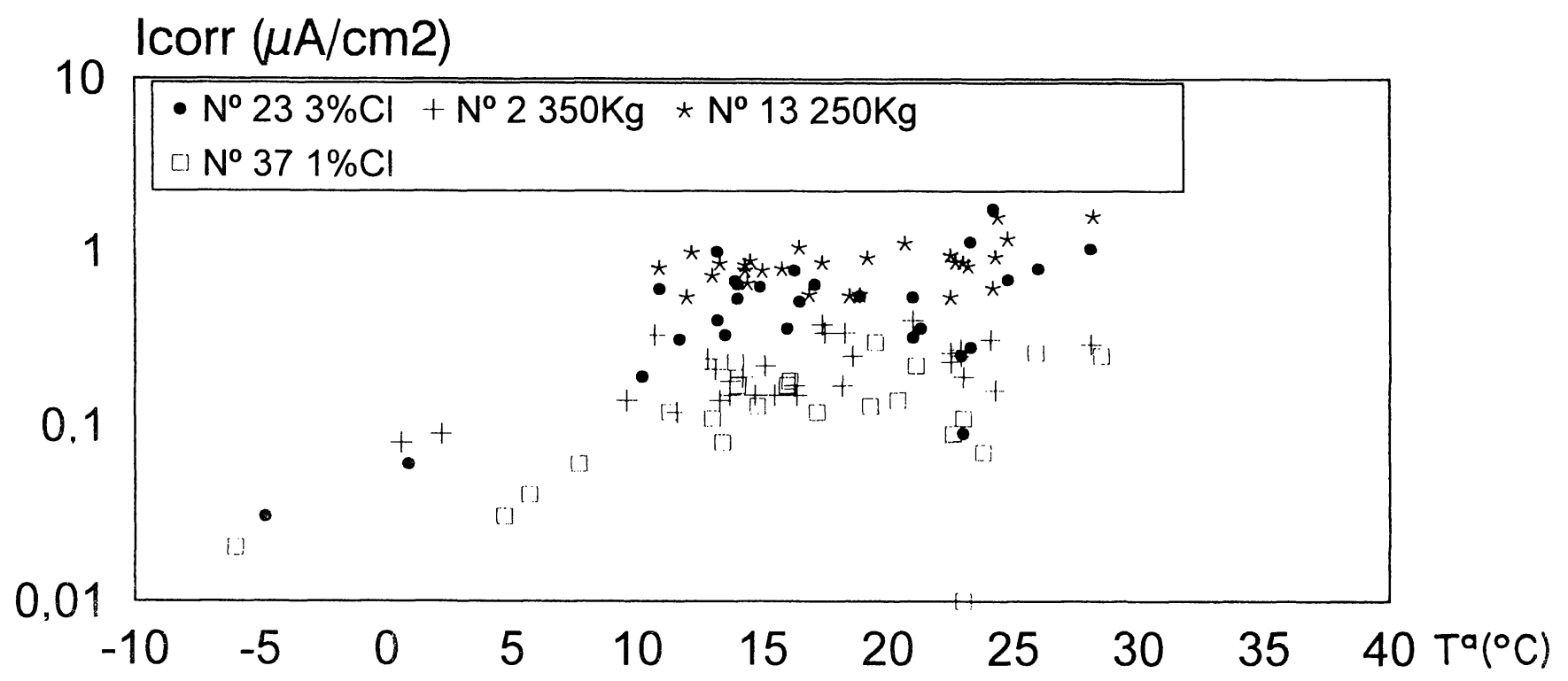

Fig. 7.- Relación entre la Icorr y la $T^{\mathrm{a}}$ para los hormigones expuestos a la atmósfera exterior.

Fig. 7.- Plot of Icorr versus $T$ in concretes exposed to outdoor conditions.

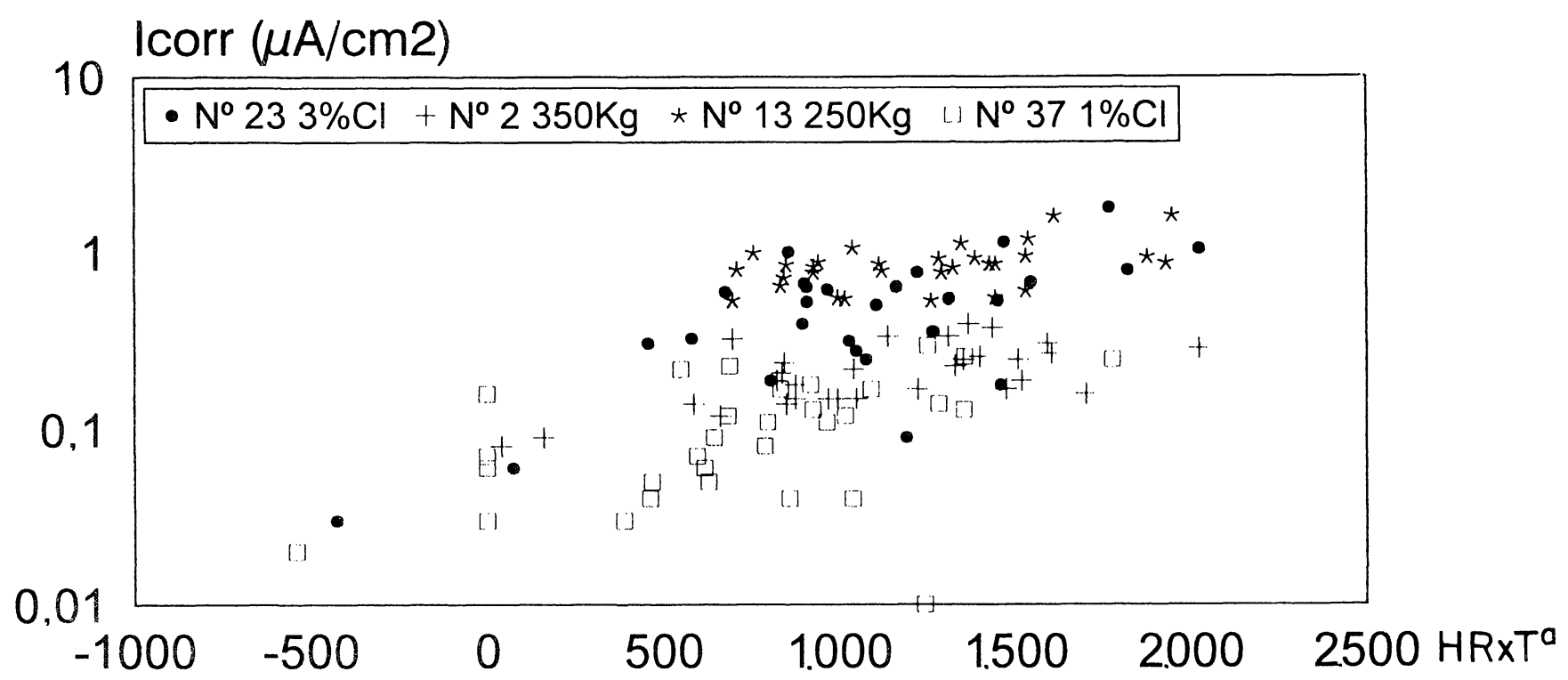

Fig. 8.- Relación entre la Icorr y la $T^{n}$ x HR-In para las mismas probetas que la figura anterior.

Fig. 8.- Plot of Icorr versus Tx Internal RH for the same concrete of previous figure. 


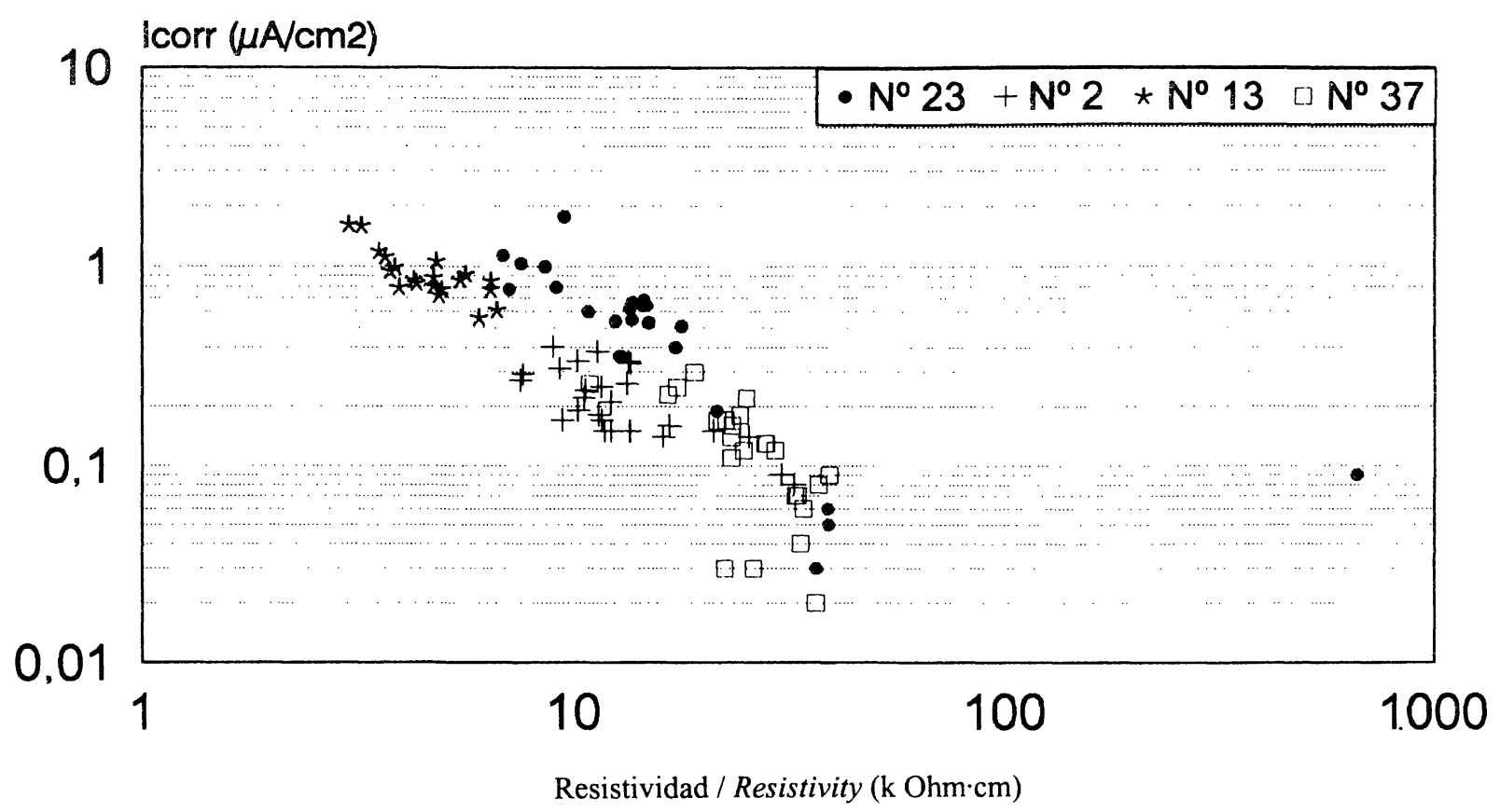

Fig. 9.- Relación entre Icorr y resistividad $(\rho)$ de los datos mostrados en la figura 5.

Fig. 9.- Relation between Icorr and resistivity $(\rho)$ derived from the values of figure 5.

\section{CONCLUSIONES}

Las conclusiones que se han podido deducir de la presente experimentación son:

1) En la solución de los poros (FAP), el aumento de la $\mathrm{T}^{\mathrm{a}}$ produce un descenso en la solubilidad del $\mathrm{Ca}(\mathrm{OH})_{2}$ y del oxígeno lo que contrabalancea el posible aumento de la Icorr. La relación $\mathrm{Cl}^{-} / \mathrm{OH}^{-}$ aumenta marcadamente cuando lo hace la $\mathrm{T}^{\mathrm{a}}$

2) En el hormigón, se desarrollan simultáneamente varios procesos cuando se producen las variaciones de HR y $\mathrm{T}^{\mathrm{a}}$ lo que hace muy improbable la posibilidad de aplicación de la ley de Arrhenius.

3) En el hormigón, el aumento de la $T^{\mathrm{a}}$ induce una evaporación y, su disminución, una condensación, que cuando se producen de forma continua, debido a los ciclos día-noche, amortigua los cambios de HR dentro de los poros. El contenido en humedad total en el hormigón disminuye cuando la $\mathrm{T}^{\mathrm{a}}$ aumenta.

4) Por debajo de $10^{\circ} \mathrm{C}$, en el hormigón la Icorr disminuye con la $\mathrm{T}^{\mathrm{a}}$, sin embargo entre 10 y $25^{\circ} \mathrm{C}$, la Icorr sólo aumenta ligeramente.

5) El mejor ajuste de los valores de Icorr se produce con la resistividad. La relación encontrada Icorr $=104 / \rho$, es la misma que en trabajos anteriores realizados en probetas de mortero o con estructuras reales.

\section{CONCLUSIONS}

The conclusions that can be drawn up from present research are:

1) In the pore solution (FAP) when $T$ rises, induces a decrease in the solubility of $\mathrm{Ca}(\mathrm{OH})_{2}$ and $\mathrm{O}_{2}$ that counterbalances the increase of corrosion rate. The $\mathrm{Cl} / \mathrm{OH}^{-}$ratio increases dramatically when $\mathrm{T}$ does.

2) In concrete several processes develop simultaneously to the variations of temperature and $R H$, which makes unlikely the possibility of applications of Arrhenius law to the corrosion process.

3) In concrete, the increase in $T$ induces an evaporation and its decrease a condensation, that when occurring continuously due to day-night evolution, buffers the RH inside the pores. The total moisture content of the concrete is smaller as $T$ increases.

4) In concrete below $10^{\circ} \mathrm{C}$ the Icorr values decrease with $\mathrm{T}$, however from 10 to $25^{\circ} \mathrm{C}$ the Icorr only slightly increases.

5) The best fit of Icorr is found versus the resistivity. This fit approaches relatively well the expression Icorr $=10^{4} / \rho$ previously found for mortar specimens and in real structures. 


\section{AGRADECIMIENTOS}

Los autores desean agradecer al CDTI la financiación que ha permitido la colaboración de J. Sarría, así como a la DG-XII de la UE por los fondos aportados para el proyecto Brite BR-4062 "The Residual Life of Reinforced Concrete Structures" para el que se han realizado parte de los ensayos.

\section{ACKNOWLEDMENTS}

The authors would tike to than the "Centro para el Desarrollo Tecnológico Industrial”, CDTI for supporting the work of J. Sarria and to the DG-XII of the UE for the fundings provided by means of the Brite Project BR-4062 "The Residual Life of Reinforced Concrete Structures".

\section{BIBLIOGRAFÍA}

(1) GONZÁLEZ, J.A., ALGABA S. y ANDRADE, C.: “Corrosion of reinforcing bars in carbonated concrete”, British. Corros. J., Vol. $15 n^{\circ} 3,(1980)$ 135-139.

(2) ANDRADE, C., ALONSO, C.: "Durability design based on models for corrosion rates. The modelling of microstructure and its potential for studying transport properties and durability”, H. Jennings, K. Scrivener, J. Kropp, Ed. Kluwer Academic Publishers. Printed in Netherlands (1996) 473-492.

(3) GLASS, G.K., PAGE, C.L., SHORT, N.R.: "Factors affecting the corrosion rate of steel in carbonated mortars", Corrosion Science 32 (1991) 1283-1294

(4) HOPE, B.B., Ip, A.K.C.: "Corrosion of steel in concrete made with slag cement", ACI Materials Journal, nov.-dec. (1987) 525531.

(5) LÓPEZ, W., GONZÁLEZ, J.A., ANDRADE, C.: "Influence of temperature on the service life of rebars", Cement and Concrete Research, Vol. 23 (1993) 1130-1140.

(6) SCHIESSL, P., RAUPACH, M.: "Influence of temperature on the corrosion rate of steel in concrete containing chlorides", $1^{\text {st }}$ Int. Conference of Reinforced Concrete Materials in Hot Climates. United Arab Emirates University, Alain U.E.A, april (1994) 537549 .

(7) ANDRADE, C., SARRÍA, J., ALONSO, C.: "Statistical study on simultaneous monitoring of rebar corrosion rate and internal relative humidity in concrete structures exposed to the atmosphere", Fourth International Symposium on "Corrosion of Reinforcement in Concrete Construction', Cambridge (U.K), july 96.

(8) SELLEVOLD, E.J.: "Resistivity and humidity measurements of repaired and non repaired areas in Gimsøystraumen bridge", Int. Conference on Repair of concrete Structures, Svolvaer (Norway), may 97.

(9) ANDRADE, C., GONZÁLEZ, J.A.: "Quantitative measurements of corrosion rate of reinforcing steels embedded in concrete using polarization resistance measurements",Werkstoffe und Korrosion 29, (1978)515-519W. Und K. 78.

(10) ALAMÁN, A.: “Condensaciones”, Rev. BIA, no.187, feb (1997) 83-97.

(11) ALONSO, C., ANDRADE, C. y GONZÁLEZ, J.A.: "Relation between concrete resistivity and corrosion rate of reinforcements in carbonated mortar made with several cement types", Cement and Concrete Research, vol. 18 (1988) 687-698.

(12) ANDRADE, C., ALONSO, C.: "Corrosion rate monitoring in the laboratory and on-site", Construction and Building Materials, Vol. 10, No. 5 (1996) 315-328 